\title{
PROSPEK MINERALISASI EMAS DAN PERAK TIPE HIDROTERMAL DI PULAU JAWA BAGIAN BARAT DENGAN PENDEKATAN ANALISIS SPASIAL LIKELIHOOD RATIO
}

\author{
Oleh: \\ Denni Widhiyatna dan Penny Oktaviani \\ Pusat Sumber Daya Geologi \\ Jalan Soekarno-Hatta No.444, Bandung
}

\section{SARI}

Indonesia memiliki rangkaian busur magmatik yang merupakan jalur mineralisasi logam. Untuk mendelineasi daerah prospek mineral emas-perak di daerah potensial tersebut, dapat digunakan metode pemetaan potensi sumberdaya mineral yang diolah dengan Sistem Informasi Geografis (SIG). Kajian ini bertujuan untuk menganalisis hubungan antara deposit emas $(\mathrm{Au})$ - perak $(\mathrm{Ag})$ tipe hidrotermal dengan faktor-faktor yang berhubungan dan mengintegrasikan hubungan tersebut menggunakan model likelihood ratio yang merupakan salah satu model dalam metode probabilitas. Kajian ini menggunakan SIG sebagai alat untuk mendelineasi area-area yang berpotensi dan belum tersentuh kegiatan eksplorasi secara langsung.

Pendekatan empiris ini berdasarkan asumsi bahwa semua deposit mempunyai genesa yang sama, dan mencakup tiga langkah utama yaitu identifikasi hubungan spasial, penghitungan dan integrasi hasil penghitungan dari berbagai faktor yang berhubungan. Untuk itu diperlukan basis data spasial yang terdiri dari lokasi mineralisasi, litologi, sesar, geokimia, dan geofisika pada lokasi kajian untuk dikompilasi, dievaluasi, dan diintegrasikan menggunakan model likelihood ratio sehingga menghasilkan peta indeks potensi mineral di Pulau Jawa Bagian Barat.

Peta indeks potensi mineral yang dihasilkan kemudian diverifikasi secara statistik yaitu membandingkan hasil dengan titik lokasi cebakan mineral yang telah ada dimana hasilnya berupa besaran akurasi untuk model likelihood ratio. Kemudian setelah diperoleh beberapa lokasi yang memiliki nilai indeks tinggi selanjutnya dilakukan uji petik lapangan pada daerah terpilih untuk membandingkan dengan kondisi sebenarnya di lapangan.

Kata kunci: Au-Ag, likelihood ratio, pemetaan potensi, SIG.

\section{ABSTRACT}

Indonesia has several magmatic arcs, where mineralization zones took place. There are many remote area along the arc which might become the area of gold-silver mineralization. Mineral resource potential mapping using GIS is an important procedure in mineral resource assessment in remote area. The aim of this study is to analyze the relationships between gold (Au)-silver (Ag) mineral deposits with their related factors, and to integrate the relationships using likelihood ratio model as one of the probabilistic methods. This study is using Geographic Information System (GIS) as a tool to identify areas that have not been subjected to the same degree of exploration. Here, a variety of spatial geological data were compiled, evaluated and integrated to produce potential Au-Ag deposits map in study area.

This empirical approach assumed that all deposits share a common genesis and comprised three main steps: the identification of spatial relationships, their quantification and the integration of multiple quantified relationships. For this, a spatial database consists of gold (Au)-silver (Ag) mineralization location, lithology, faults, geochemical, and geophysical data is needed to construct mineral potential index map at western Java Island using likelihood ratio model in GIS.

The mineral potential index map was then verified by comparing the result with existing mineral deposit locations, the result will give the respective accuracies for the likelihood ratio model.

Keywords: Au-Ag, likelihood ratio, potential mapping, GIS. 


\section{PENDAHULUAN}

\section{Latar Belakang}

Indonesia merupakan negara yang memiliki potensi sumber daya geologi yang relatif berlimpah, diantaranya berupa potensi mineral logam. Kajian eksplorasi mineral logam telah dilakukan sejak lama oleh berbagai pihak, baik itu pemerintah maupun swasta untuk memenuhi kebutuhan akan berbagai jenis mineral logam.

Logam emas dan perak merupakan logam mulia yang banyak diminati karena nilai ekonomisnya yang tinggi. Di Indonesia, eksplorasi untuk kedua jenis mineral ini telah dilakukan sejak masa penjajahan Belanda hingga kini eksplorasi secara langsung ke lapangan atau dengan melakukan berbagai studi literatur, analisis penginderaan jauh, hingga melakukan pemodelan.

Adanya perkembangan teknologi yang pesat dalam bidang Sistem Informasi Geografis (SIG) memungkinkan untuk melakukan berbagai analisis atau pemrosesan data untuk membuat model dalam rangka mencari daerah-daerah yang kemungkinan merupakan zona mineralisasi. Teknik ini memiliki keuntungan dilihat dari segi ekonomi karena tidak memerlukan banyak waktu dan biaya untuk eksplorasi pendahuluan ke lapangan. Teknik ini penting dilakukan untuk mendelineasi daerahdaerah mineralisasi sebelum dilakukan kajian eksplorasi lapangan.

\section{Maksud dan Tujuan}

Maksud kajian ini yaitu men gidentifikasi daerah-daerah prospek mineralisasi logam Au-Ag dari data geokimia, geofisika, litologi, struktur geologi, dan titik-titik keterdapatan mineral logam dengan cara diproses menggunakan SIG.

Tujuan kajian ini untuk mendelineasi daerah prospek emas dan perak di lokasi kajian dalam bentuk peta indeks potensi mineral dari data sekunder yang tersedia.

\section{Lokasi Kajian}

Lokasi kajian mencakup Pulau Jawa bagian barat (Gambar 1) yang memiliki potensi sumberdaya mineral yang cukup berlimpah dan mempunyai data penyebaran potensi mineral yang mencukupi untuk diolah dengan menggunakan sistem SIG.

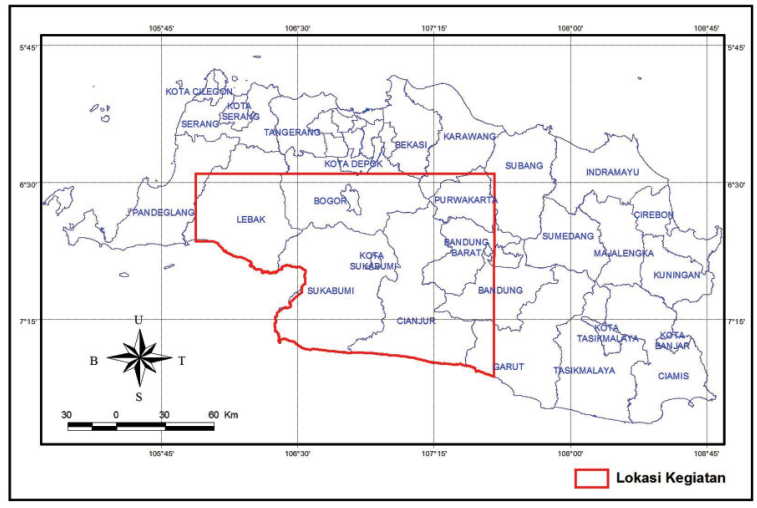

Gambar 1. Lokasi Kajian

\section{Metode dan Sistimatika Kajian}

\section{Metode}

ini meliputi:

Metode yang dilakukan dalam kajian

1. Pengumpulan data potensi sumber daya geologi dan administrasi daerah Pulau Jawa bagian barat (dalam format shapefile).

2. Pengumpulan data geokimia sedimen sungai aktif dan geofisika berupa data anomali bouguer yang diikuti dengan proses pendigitasian dan mentransfer data ke dalam bentuk shapefile.

3. Pembuatan aplikasi nilai kemungkinan dan pembuatan data statistik, model untuk pembuatan peta potensi mineral berbasis SIG.

4. Menyusun basisdata SIG.

5. Verifikasi peta potensi mineral secara statistik dan peninjauan ke lapangan.

\section{Sistematika} meliputi :

Sistematika kajian yang dilakukan

1. Persiapan dan studi literatur.

2. Pengumpulan dan kompilasi data wilayah administratif, geologi, geokimia, geofisika, dan titik keterdapatan mineral logam.

3. Penyusunan data spasial wilayah administratif, geologi, geokimia, geofisika, dan titik keterdapatan mineral logam Au dan Ag.

4. Pemrosesan dan integrasi data untuk penyusunan Peta Potensi Keterdapatan Mineral Logam Au dan Ag.

Di dalam proses pemetaan potensi mineral dengan menggunakan SIG secara rinci dilaksanakan dalam empat tahap (Lee \&Oh, 2008):

1. Penyusunan basis data spasial, 
2. Pemrosesan data dari basis data peta. deposit mineral dan faktor-faktor lain di tampilkan dalam SIG, dan hubungan ditentukan secara kuantitatif menggunakan model probabilitas dan statistik, menghasilkan beberapa buah peta.

3. Aplikasi dan integrasi model untuk menyusun peta potensi mineral (Gambar.2).

4. Verifikasi peta potensi menggunakan deposit mineral yang sudah diketahui.

Peta yang dihasilkan memberikan indikasi dalam skala yang ditetapkan daerah yang tepat untuk ditindaklanjuti dalam kajian eksplorasi, tidak memberikan perkiraan jumlah dan ukuran deposit mineral.

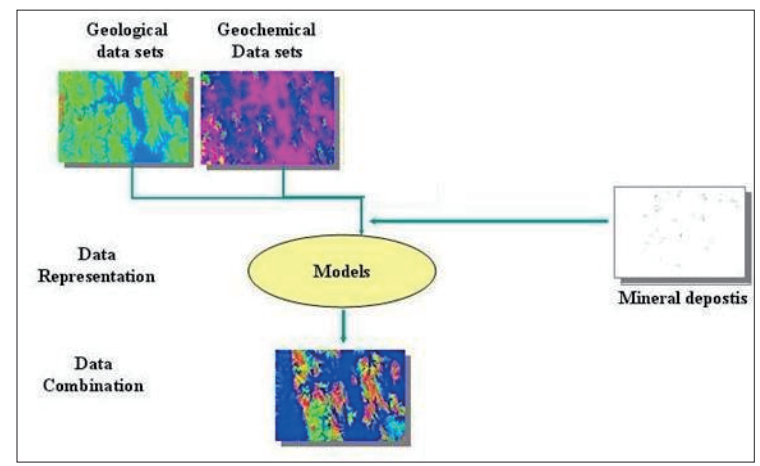

Gambar 2. Bagan Alir Integrasi Model.

\section{GEOLOGI REGIONAL DAERAH KAJIAN}

\section{Tataan Geologi}

Lokasi kajian termasuk ke dalam Busur Sunda-Banda (Gambar.3) yang merupakan busur magmatik terpanjang di Indonesia, melampar dari utara Sumatera melewati Jawa ke arah timur. Segmen barat terdiri dari Sumatera, Jawa Barat, dan sebagian Jawa Tengah, dan terbentuk pada tepian selatan Paparan Sunda, bagian timur mulai dari Jawa Tengah ditafsirkan sebagai busur kepulauan yang terbentuk pada kontinen yang tipis.

Mineralisasi emas yang terdapat pada busur ini merupakan $20 \%$ dari emas di Indonesia, dan $14 \%$ tembaga Indonesia juga terdapat di busur ini. Segmen kontinen bagian barat dicirikan oleh banyaknya cebakan epitermal sistem urat tipe sulfidasi rendah. Mineralisasi emas dengan batuan induk sedimen dalam skala kecil dijumpai di Cikotok.

Menurut Sunarya (1998), dalam Widhi drr (2009), terdapat 10 zona mineralisasi di daerah Jawa Barat dan Banten Tujuh zona mineralisasi terdapat di Provinsi Jawa Barat, meliputi : Kubah Jampang, Gunung Cariu, Cikondang, Purwakarta, Soreang, Gunung Sawal dan Garut - Tasikmalaya. Sedangkan 3 (tiga) zona mineralisasi terdapat di Provinsi Jawa Barat dan Banten yaitu Kubah Bayah, Gunung Limbung - Cibugis dan Gunung Ciawitali-Pongkor.

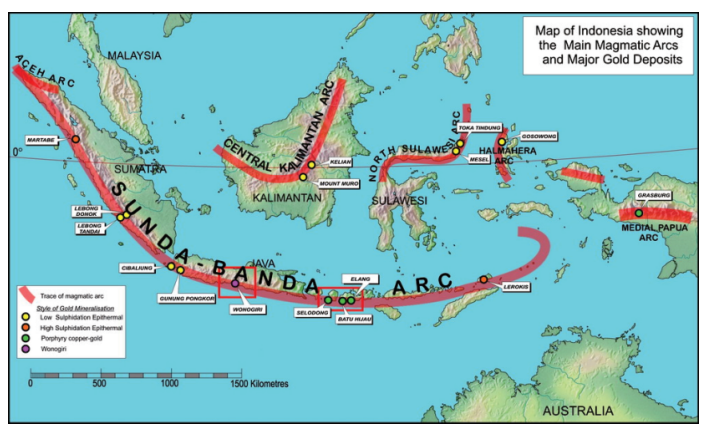

Gambar 3. Busur magmatik utama dan cebakan emas besar di Indonesia

(http://www.southernarcminerals.com/projects/).

Zona-zona mineralisasi tersebut umumnya merupakan zona mineralisasi logam mulia dan logam dasar yang terdapat dalam suatu deretan pegunungan selatan Jawa Barat yang ditempati oleh Formasi Andesit Tua (van Bemmelen, 1949) yang diindikasikan sebagai tempat kedudukan mineralisasi (Gambar.4).

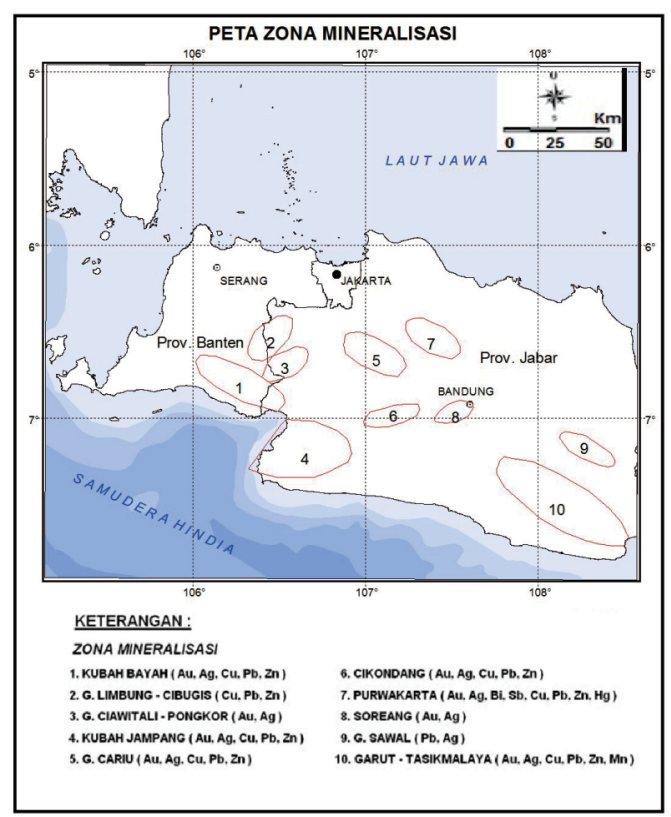

Gambar 4. Zona Mineralisasi Logam di Wilayah Jawa Barat dan Banten (Sunarya, 1997) 


\section{KERANGKA PIKIR PENGGUNAAN DATA}

Bateman (1956), dalam Rifki Febrianto, 2011, menyatakan bahwa larutan hidrotermal adalah suatu cairan atau fluida yang panas, kemudian bergerak naik ke atas dengan membawa komponen-komponen mineral logam, fluida ini merupakan larutan sisa yang dihasilkan pada proses pembekuan magma. Alterasi dan mineralisasi adalah suatu bentuk perubahan komposisi pada batuan baik itu kimia, fisika ataupun mineralogi sebagai akibat pengaruh cairan hidortermal pada batuan, perubahan yang terjadi dapat berupa rekristalisasi, penambahan mineral baru, larutnya mineral yang telah ada, penyusunan kembali komponen kimianya atau perubahan sifat fisik seperti permeabilitas dan porositas batuan (Pirajno, 1992).

Alterasi dan mineralisasi bisa juga termasuk dalam proses pergantian unsurunsur tertentu dari mineral yang ada pada batuan dinding digantikan oleh unsur lain yang berasal dari larutan hidrotermal sehingga menjadi lebih stabil. Proses ini berlangsung dengan cara pertukaran ion dan tidak melalui proses pelarutan total, artinya tidak semua unsur penyusun mineral yang digantikan melainkan hanya unsurunsur tertentu saja.

Alterasi hidrotermal merupakan proses yang kompleks yang melibatkan perubahan mineralogi, kimiawi, tekstur, dan hasil interaksi fluida dengan batuan yang dilewatinya. Perubahan-perubahan tersebut akan bergantung pada karakter batuan dinding, karakter fluida (Eh, $\mathrm{pH})$, kondisi tekanan maupun temperatur pada saat reaksi berlangsung, konsentrasi, serta lama aktifitas hidrotermal. Walaupun faktor-faktor di atas saling terkait, tetapi temperatur dan kimia fluida kemungkinan merupakan faktor yang paling berpengaruh pada proses alterasi hidrotermal.

Basis data spasial yang diasumsikan berhubungan dengan keterdapatan potensi mineralisasi dikumpulkan (Tabel.3), terdapat empat faktor atribut yang dianggap menentukan keterdapatan potensi mineralisasi. Keempat faktor ini dibuat data spasialnya dengan cara mendigitasi ulang (seperti data geofisika anomali Bouguer), dan mengolah secara spasial data lain yang diperlukan ke dalam bentuk shapefile.

Tabel 3.

Peta atribut yang digunakan dalam permrosesan data.

\begin{tabular}{|l|l|l|}
\hline No & Peta Atribut & \multicolumn{1}{c|}{ Deskripsi } \\
\hline 1 & $\begin{array}{l}\text { Peta Sebaran } \\
\text { Litologi }\end{array}$ & $\begin{array}{l}\text { Unit litologi/batuan yang } \\
\text { menyusun lokasi kajian. }\end{array}$ \\
\hline 2 & $\begin{array}{l}\text { Peta Struktur } \\
\text { Geologi }\end{array}$ & $\begin{array}{l}\text { Diperlukan untuk } \\
\text { mengklasifikasikan jarak } \\
\text { dari struktur (sesar). }\end{array}$ \\
\hline 3 & $\begin{array}{l}\text { Peta Anomali } \\
\text { Bouger }\end{array}$ & $\begin{array}{l}\text { Anomali yang } \\
\text { disebabkan oleh adanya } \\
\text { deposit bijih logam berat } \\
\text { dan densitas batuan. }\end{array}$ \\
\hline 4 & $\begin{array}{l}\text { Peta Lokasi } \\
\text { Gonto }\end{array}$ & $\begin{array}{l}\text { Mengklasifikasikan } \\
\text { sebaran unsur (16 unsur: } \\
\text { Ag, Al, As, Au, Co, Cr, } \\
\text { Cu, Fe, Hg, Mn, Mo, Ni, } \\
\text { Pb, Ti, V, Zn). }\end{array}$ \\
\hline 5 & $\begin{array}{l}\text { Peta Titik } \\
\text { Potensi Mineral }\end{array}$ & $\begin{array}{l}\text { Lokasi keterdapatan } \\
\text { mineralisasi Au-Ag. }\end{array}$ \\
\hline
\end{tabular}

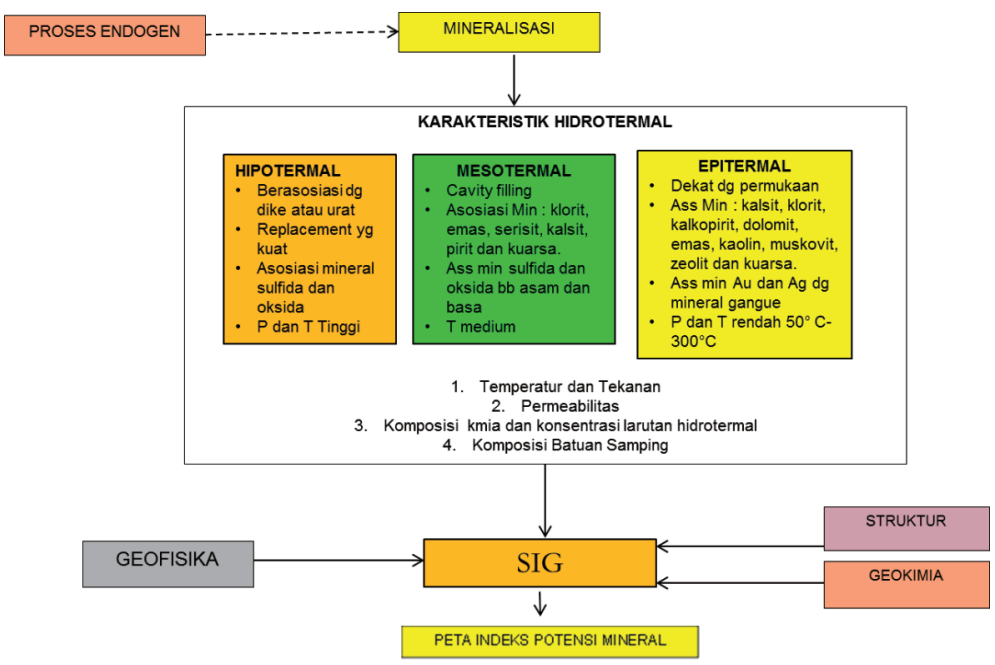

Gambar 5. Kerangka Pikir Kajian 


\section{Metode SIG untuk Pembuatan Peta Indeks Potensi Mineral}

Metode yang dipergunakan didalam kajian ini adalah aplikasi Sistem Informasi Geografis menggunakan perangkat lunak Arc View 3.3. untuk integrasi model perhitungan probabilitas. Model yang dipakai untuk aplikasi adalah likelihood ratio.

\section{Model Probabilitas "Likelihood ratio"}

Model likelihood ratio merupakan salah satu aplikasi dari teori probabilitas Bayesian yang telah banyak diaplikasikan untuk analisis potensi mineral diantaranya dalam Bonham-Carter (1994) dan Lee \&Oh, (2008).

Jumlah unit sel dinyatakan dalam $N\{D\}$, mengandung deposit mineral $\mathbf{D}$, dan jumlah total sel $\mathrm{N}\{T\}$, probabilitas dari kemunculan deposit mineral dinyatakan dalam;

$$
P\{D\}=\frac{N\{D\}}{N\{T]}
$$

Selanjutnya apabila pola binary predictor pattern $B$ melingkupi $N\{D \cap B\}$ unit cell hadir didalam area dan sejumlah deposit mineral yang diketahui hadir sebelumnya didalam pattern adalah $N\{D \cap B\}$ kemudian favorabilitas dari deposit dengan kemunculan predictor $(B)$ dan probabilitas dari ketidakmunculan deposit (B) dapat diekspresikan dalam conditional probabilitas sebagai berikut:

$$
\begin{aligned}
& P\{D \mid B\}=\frac{P\{D \cap B\}}{P\{B\}}=P\{D\} \frac{P\{B \mid D\}}{P\{B\}} \\
& P\{D \mid \bar{B}\}=\frac{P\{D \cap \bar{B}\}}{P\{\bar{B}\}}=P\{D\} \frac{P\{\bar{B} \mid D\}}{P\{\bar{B}\}}
\end{aligned}
$$

Posteriori probability dari ke munculan deposit dan ketidakmunculan deposit dari favorable predictor pattern dinotasikan dalam $P\{D \mid B\}$ dan $P\{D \mid \bar{B}\} . P\{D \mid B\}$ dan $P\{D \mid \bar{B}\}$ adalah posteriori probabilities di dalam dan di luar predictor pattern $B$ yang memberikan kemunculan deposit $D . P\{B\}$ dan $P\{\bar{B}\}$ adalah priori probabilities dari kemunculan predictor pattern $B$.

Odds (O) didefinisikan sebagai $O=P /(1-P)$ persamaan 2 dan 3 menjadi:

$$
\begin{aligned}
& O\{D \mid B\}=O\{D\} \frac{P\{B \mid D\}}{P\{B \mid \bar{D}\}} \\
& O\{D \mid \bar{B}\}=O\{D\} \frac{P\{\bar{B} \mid D\}}{P\{\bar{B} \mid \bar{D}\}}
\end{aligned}
$$

Dimana $O\{D \mid B\}$ and $O\{D \mid \bar{B}\}$ masingmasing adalah posteriori odds dari deposit yang memberikan kemunculan dan ketidakmunculan dari binary predictor pattern $B$ dan $O\{D\}$ adalah priori odds dari kemunculan.

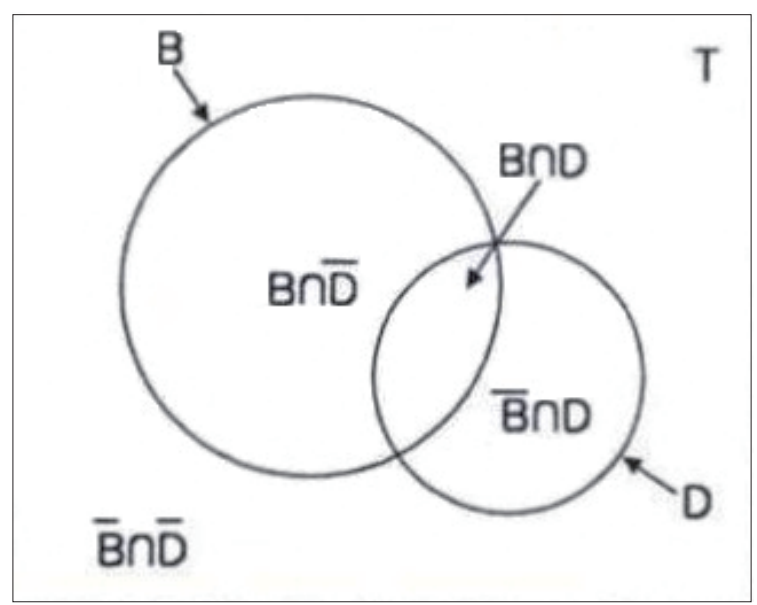

Gambar 6. Diagram yang menggambarkan Likelihood Ratio.

$\mathrm{T}=$ Total area,

$\mathrm{B}=$ Binary predictor pattern present,

(B) = Binary predictor pattern absent,

D = Mineral deposit occurrence present,

(D) = Mineral deposit occurrence absent

Dari masing-masing data spasial dihasilkan nilai Frequency Ratio (FR) yang kemudian dilakukan komputasi dengan ArcView mengikuti persamaan:

$$
\mathrm{LSIL}=\sum \mathrm{Lr}
$$
$\begin{aligned} & \text { Fc }=\text { likelihood ratio dari masing-masing } \\ & \text { faktor atau tipe }\end{aligned}$

\section{AKUISISIDATA}

Analisis potensi mineralisasi menggunakan model probabilitas Likelihood Ratio didasari oleh hubungan antara keterdapatan lokasi potensi mineralisasi dengan faktor-faktor atributnya. Oleh karena itu, untuk memprediksi keterdapatan potensi mineralisasi, perlu asumsi bahwa keterdapatan potensi mineralisasi ditentukan oleh faktor-faktor tertentu, dan hal tersebut akan terjadi di lokasi berbeda dengan kondisi yang sama.

\section{Material}

Material yang digunakan untuk analisis spasial pada kajian ini pada dasar- 
nya dibagi menjadi dua jenis; perangkat keras (hardware) dan perangkat lunak (software). Material tersebut digunakan untuk mengekstrak, memproses, dan menganalisis informasi yang diinginkan dari data primer yang dimiliki.

\section{Perangkat Keras (Hardware)}

Data yang dipakai dalam kajian ini meliputi gabungan dari litologi dan struktur geologi yang diambil dari Peta Geologi skala 1: 100.000 Lembar Balekambang, Bogor, Cianjur, Jampang, Leuwidamar, dan Sindangbarang. Peta tematik lain yang digunakan yaitu Peta Anomali Bouguer skala 1 : 100.000 terbitan Pusat Penelitian dan Pengembangan Geologi.

\section{Perangkat Lunak (Software)}

Perangkat lunak Sistem Informasi Geografis (SIG) yang digunakan dalam kajian ini adalah ArcGIS 9.2, ArcView GIS 3.3 dan Mapinfo Professional 9.0. Aplikasi perangkat lunak ini merupakan peralatan basis data spasial $100 \mathrm{~m} \times 100 \mathrm{~m}$.

\section{Pengolahan Data Geokimia}

Hasil pemrosesan basis data spasial geokimia sebanyak 515 titik lokasi conto sedimen sungai aktif ini adalah 16 lembar peta sebaran unsur yang merupakan hasil intrapolasi meliputi : Ag, Al, As, Au, Co, Cr, $\mathrm{Cu}, \mathrm{Fe}, \mathrm{Hg}, \mathrm{Mn}, \mathrm{Mo}, \mathrm{Ni}, \mathrm{Pb}, \mathrm{Ti}, \mathrm{V}$, dan $\mathrm{Zn}$ (Gambar 6, contoh Peta Sebaran Emas (Au) di daerah kajian).

\section{Pengolahan Data Litologi}

Data litologi yang terdapat di lokasi kajian diperoleh peta geologi regional dengan skala 1: 100.000 terdiri dari 183 satuan batuan. Dari keseluruhan satuan batuan tersebut setelah dilakukan pemrosesan, diketahui bahwa keterdapatan mineralisasi Au-Ag terdapat pada sekitar 20 litologi. (Tabel.4 dan Gambar.8). Pada umumnya satuan litologi yang mengandung keterdapatan mineralisasi adalah batuan gunungapi, breksi, batuan beku seperti pada

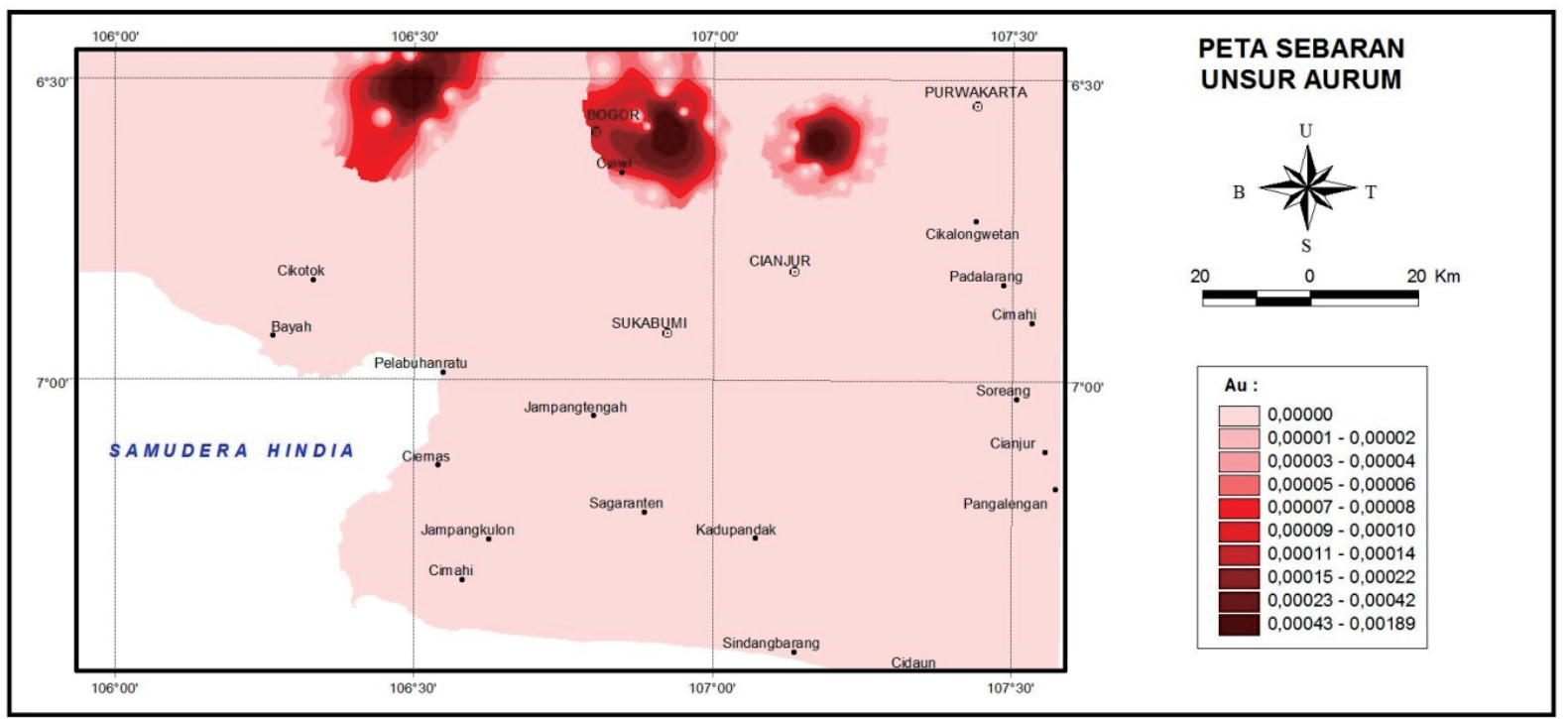

Gambar 7. Peta sebaran unsur emas (Au) di lokasi Kajian

dasar untuk manajemen spasial dan analisis data dalam penentuan lokasi potensi mineralisasi.

\section{PENGOLAHAN DATA}

\section{Pengolahan Data Spasial}

Pemrosesan data spasial geokimia, litologi, struktur, dan geofisika menggunakan software Arc View 3.3, dengan ukuran sel
Batuan Gunungapi Gunung Gede, Formasi Bentang Bagian Bawah, Formasi Jampang, Batuan Gunungapi Gunung Salak, Formasi Jampang Anggota Ciseureuh, Tuf Malingping, Formasi Cikotok, Granit Cihara, Basalt Gn. Angsana, Formasi Cimandiri, dan Formasi Beser. Sementara umur batuan tersebut bervariasi antara Holosen sampai Eosen. 


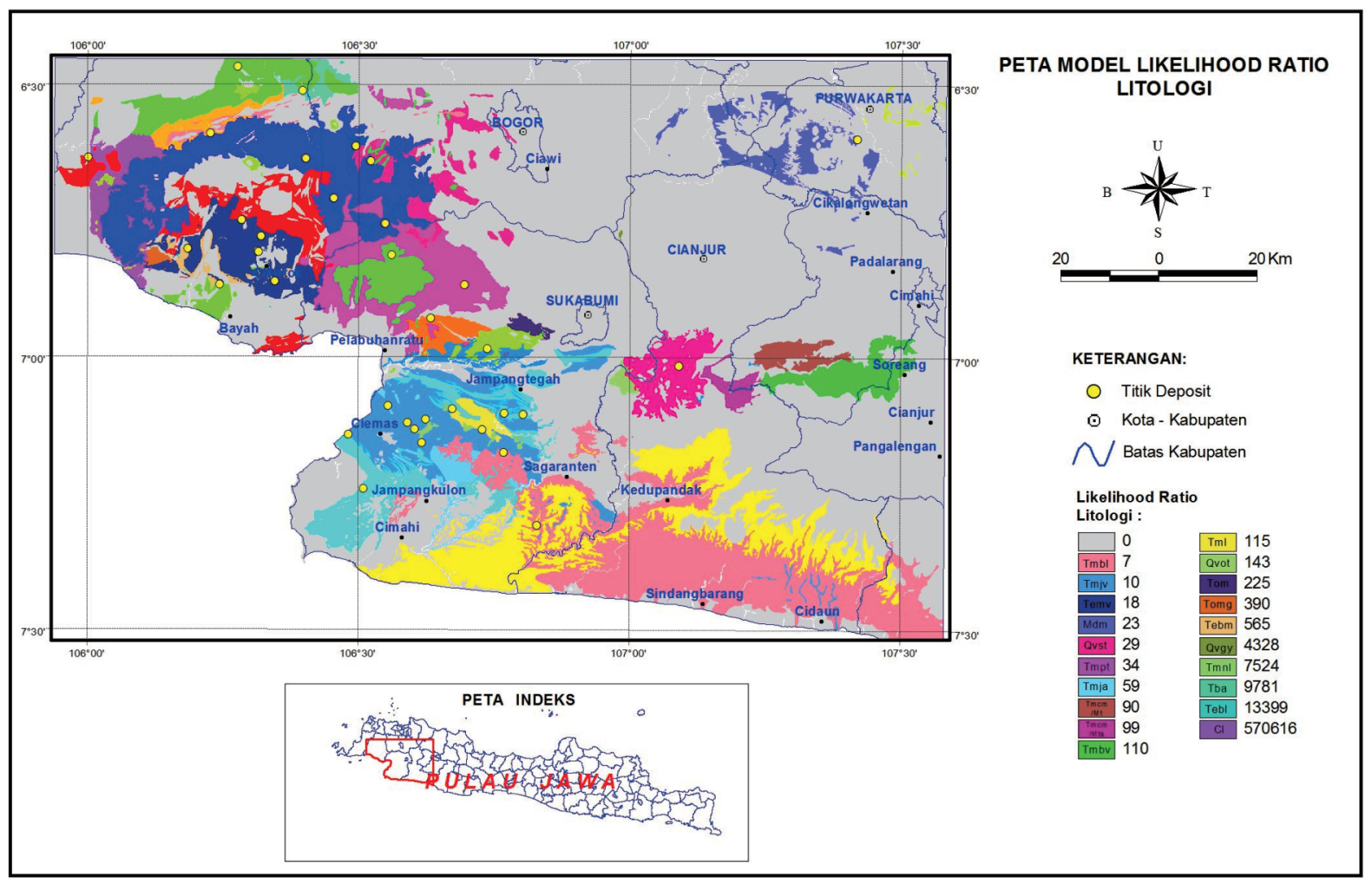

Gambar 8. Peta Model Likelihood Ratio Litologi.

Tabel 4.

Litologi Yang Mengandung Lokasi Keterdapatan Mineralisasi.

\begin{tabular}{|c|c|c|c|c|c|c|c|c|}
\hline \multirow[b]{2}{*}{ No } & \multirow[b]{2}{*}{ Formasi } & \multicolumn{2}{|c|}{ Pixel } & \multicolumn{2}{|c|}{ Keterdapatan Mineral } & \multirow{2}{*}{$\begin{array}{l}\text { Likelihood } \\
\text { ratio }\end{array}$} & \multirow[b]{2}{*}{ Umur } & \multirow[b]{2}{*}{ Keterangan Formasi } \\
\hline & & Jumlah & Persentase & $\begin{array}{l}\text { Jumlah } \\
\text { Lokasi }\end{array}$ & Persentase & & & \\
\hline 14 & Mdm & 21083 & 1,2678 & 1 & 2,941 & 2,320 & $\begin{array}{l}\text { Miosen } \\
\text { Tengah }\end{array}$ & $\begin{array}{l}\text { Formasi Jatiluhur, Anggota } \\
\text { Napal dan Batupasir Kuarsa }\end{array}$ \\
\hline 70 & Qvgy & 113 & 0,0068 & 1 & 2,941 & 432,832 & Holosen & $\begin{array}{l}\text { Batuan Gunungapi Gn. } \\
\text { Gunung Gede }\end{array}$ \\
\hline 78 & Tmbl & 128725 & 7,7408 & 2 & 5,882 & 0,760 & Miosen Atas & $\begin{array}{l}\text { Formasi Bentang Bagian } \\
\text { Bawah }\end{array}$ \\
\hline 79 & Tmjv & 46411 & 2,7909 & 1 & 2,941 & 1,054 & $\begin{array}{l}\text { Miosen } \\
\text { Bawah }\end{array}$ & Formasi Jampang \\
\hline 80 & $\mathrm{Cl}$ & 6 & 0,0004 & 7 & 20,588 & $57.061,632$ & Mio-Pliosen & Lempung \\
\hline 83 & Qvst & 16418 & 0,9873 & 1 & 2,941 & 2,979 & Holosen & Batuan Gunungapi Gn. Salak \\
\hline 88 & Tmnl & 65 & 0,0039 & 1 & 2,941 & 752,461 & $\begin{array}{l}\text { Miosen } \\
\text { Tengah }\end{array}$ & $\begin{array}{l}\text { Formasi Nyalindung, } \\
\text { Anggota Batugamping }\end{array}$ \\
\hline 90 & Qpot & 3403 & 0,2046 & 1 & 2,941 & 14,373 & Holosen & Endapan Undak Tua \\
\hline 91 & Tml & 4237 & 0,2548 & 1 & 2,941 & 11,544 & $\begin{array}{l}\text { Miosen } \\
\text { Bawah }\end{array}$ & Formasi Lengkong \\
\hline 92 & Tmja & 8268 & 0,4972 & 1 & 2,941 & 5,916 & $\begin{array}{l}\text { Miosen } \\
\text { Bawah }\end{array}$ & $\begin{array}{l}\text { Formasi Jampang, Anggota } \\
\text { Ciseureuh }\end{array}$ \\
\hline 99 & Tpmt & 14007 & 0,8423 & 1 & 2,941 & 3,492 & Pliosen & Tuf Malingping \\
\hline 101 & Temv & 27003 & 1,6238 & 1 & 2,941 & 1,811 & $\begin{array}{l}\text { Eosen- } \\
\text { Miosen }\end{array}$ & Formasi Cikotok \\
\hline 102 & Tebm & 3457 & 0,2079 & 4 & 11,765 & 56,592 & Eosen & $\begin{array}{l}\text { Formasi Bayah, Anggota } \\
\text { Batulempung }\end{array}$ \\
\hline 113 & Tomg & 1251 & 0,0752 & 1 & 2,941 & 39,097 & Oligo-Miosen & Granit Cihara \\
\hline 116 & Tebl & 73 & 0,0044 & 2 & 5,882 & $1.339,999$ & Eosen & $\begin{array}{l}\text { Formasi Bayah, Anggota } \\
\text { Batugamping }\end{array}$ \\
\hline 123 & Tba & 50 & 0,0030 & 1 & 2,941 & 978,199 & Miosen Atas & Basalt Gn. Angsana \\
\hline 167 & Tmcm/Mts & 4915 & 0,2956 & 1 & 2,941 & 9,951 & Miosen & Formasi Cimandiri \\
\hline 172 & $\mathrm{Tmcm} / \mathrm{Mt}$ & 5426 & 0,3263 & 1 & 2,941 & 9,014 & Miosen & Formasi Cimandiri \\
\hline 177 & Tom & 2167 & 0,1303 & 1 & 2,941 & 22,570 & Oligo-Miosen & \\
\hline 181 & Tmbv/Pb & 17772 & 1,0687 & 4 & 11,765 & 11,008 & Miosen Atas & Formasi Beser \\
\hline
\end{tabular}




\section{Pengolahan Data Struktur Geologi}

Peta struktur yang dihasilkan di dalam pemrosesan data ini adalah jarak terhadap kelurusan struktur sesar, hal ini diyakini mewakili peluang terjadinya proses mineralisasi yang dikontrol oleh kemunculan sesar. Di dalam daerah kajian, peta dibuat dalam 10 kelas, dimana pengaruh jarak memberikan peluang yang lebih besar terhadap terjadinya proses mineralisasi logam (Gambar.9). indeks tinggi berada di bagian selatan dan baratdaya lokasi kajian.

\section{Integrasi Data Model Likelihood Ratio}

Integrasi data bertujuan untuk mengetahui seberapa besar hubungan antara deposit mineral dengan faktor-faktor yang berhubungan. Likelihood ratio untuk range atau kelas dari masing-masing faktor dihitung untuk menentukan mineral potential indeks seperti yang terdapat pada Tabel 5 dan 6.

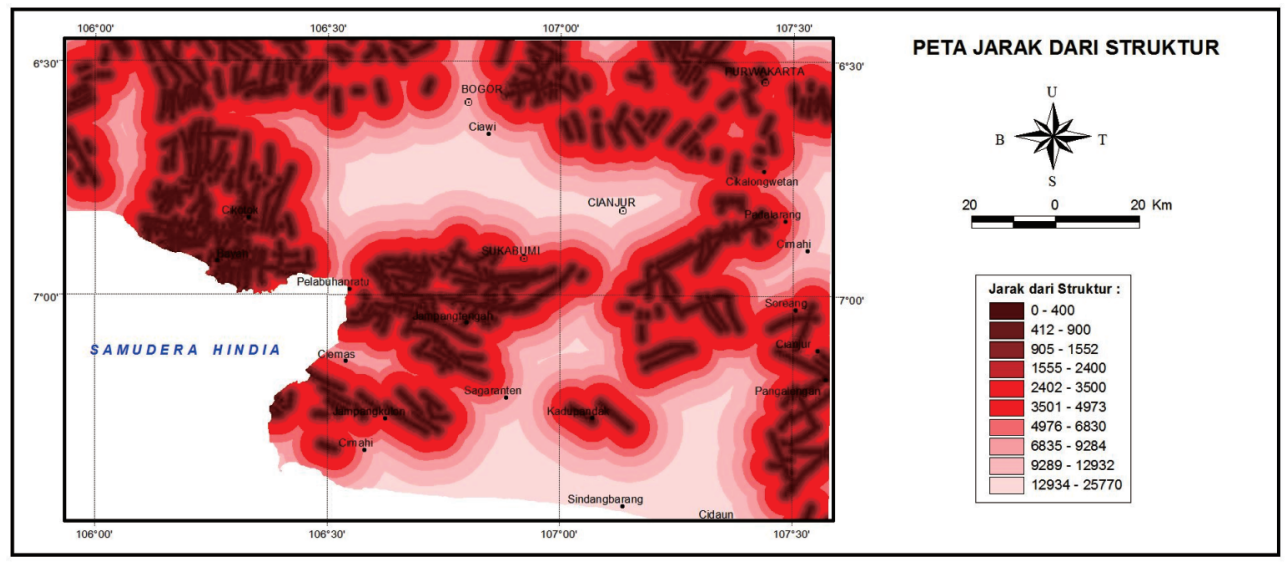

Gambar 9. Peta Jarak Dari Struktur Di Lokasi Kajian

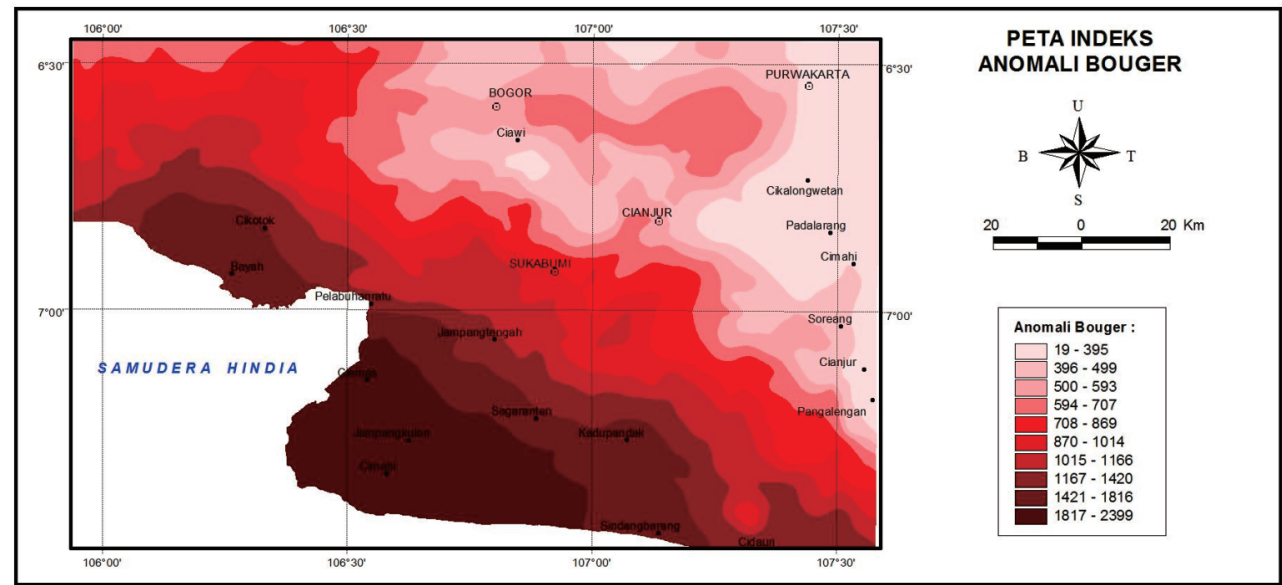

Gambar 10. Peta Indeks Anomali Bouguer Di Lokasi Kajian.

\section{Pengolahan Data Geofisika}

Pengolahan data geofisika yang berupa anomali Bouguer diproses dengan asumsi bahwa daerah yang memiliki anomali gaya berat merupakan daerah yang mengandung deposit bijih logam berat serta memiliki perbedaan densitas batuan (Kuzvart\& Bohmer, 1986). Dari Gambar.10 yang merupakan peta anomali bouguer dapat dilihat bahwa daerah yang memiliki
Hubungan spasial dari deposit mineral dan beberapa faktor atribut yang rasio area untuk total area sudah dihitung dan likelihood ratio akhirnya didapatkan dengan cara membagi rasio mineral deposit dengan rasio area. Tiap-tiap faktor atribut dibagi ke dalam 10 kelas (faktor unsur geokimia, data bouger, dan struktur geologi), kecuali untuk faktor litologi. Peta model likelihood ratio/frequency ratio dari tiap-tiap faktor atribut dapat dilihat pada gambar 11. 


\section{MAKALAH ILMIAH}

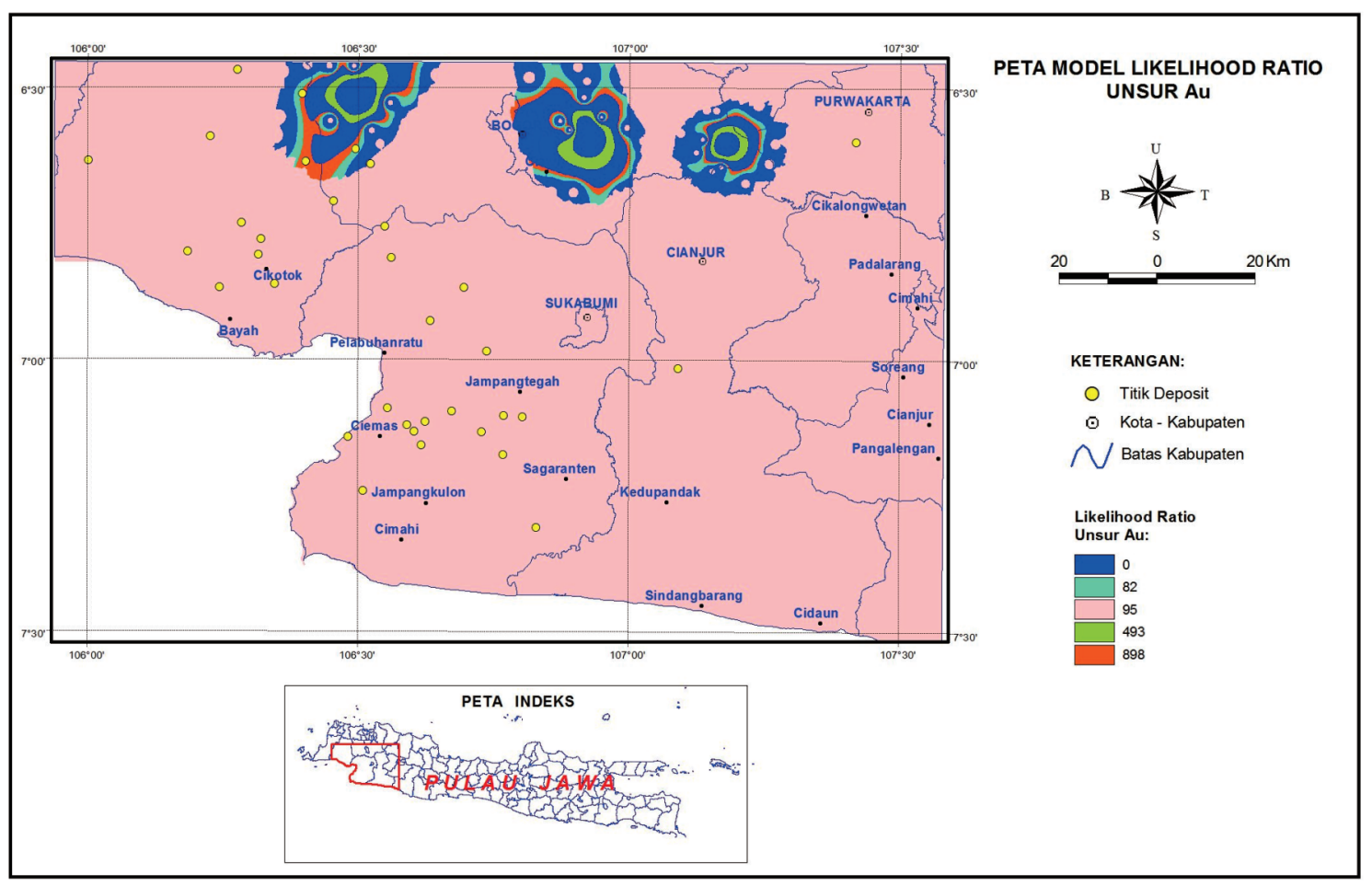

Gambar 11. Peta Model Likelihood Ratio Unsur Au dari Conto Sedimen Sungai

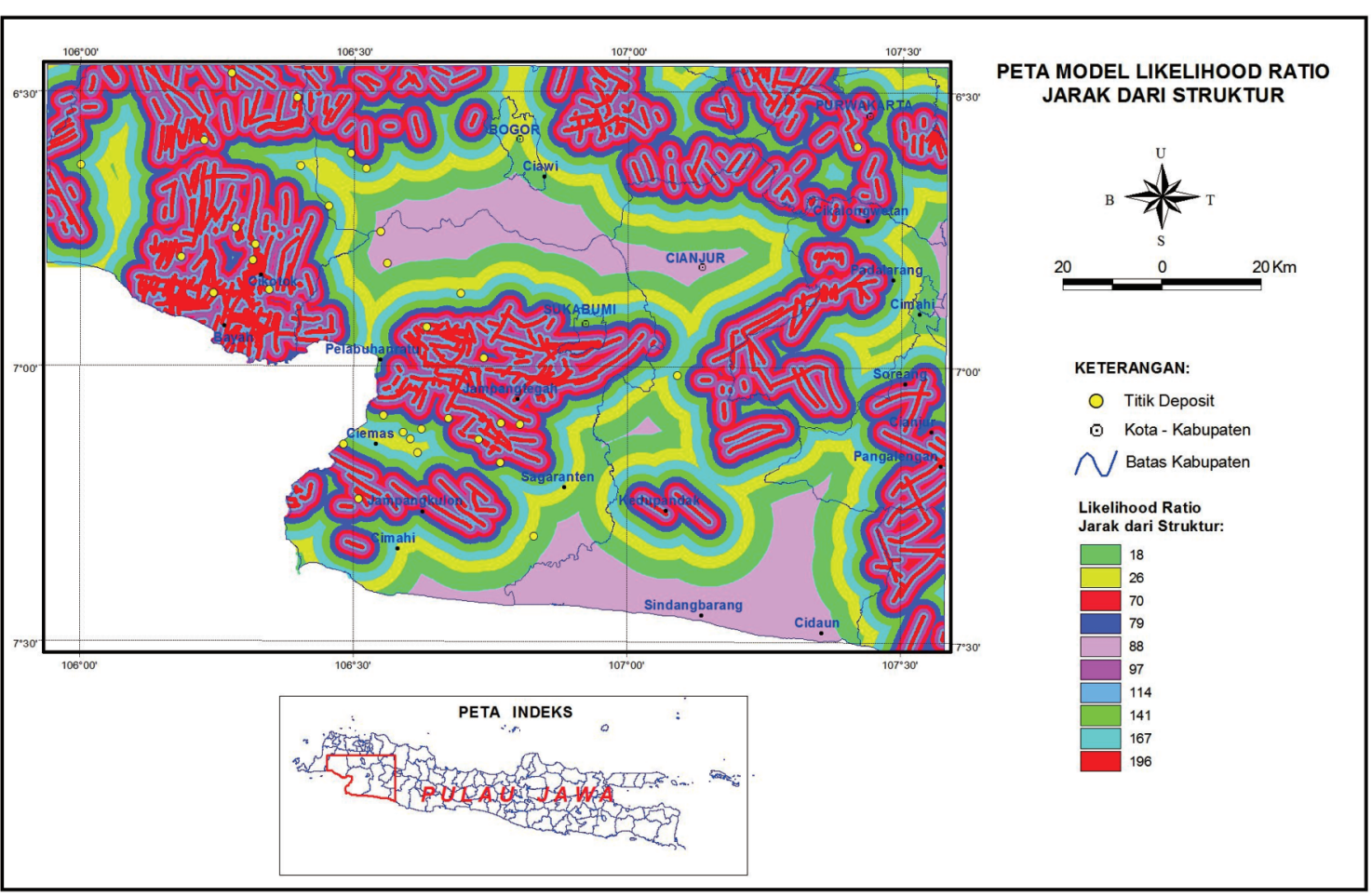

Gambar 12. Peta Model Likelihood Ratio Jarak dari Struktur 


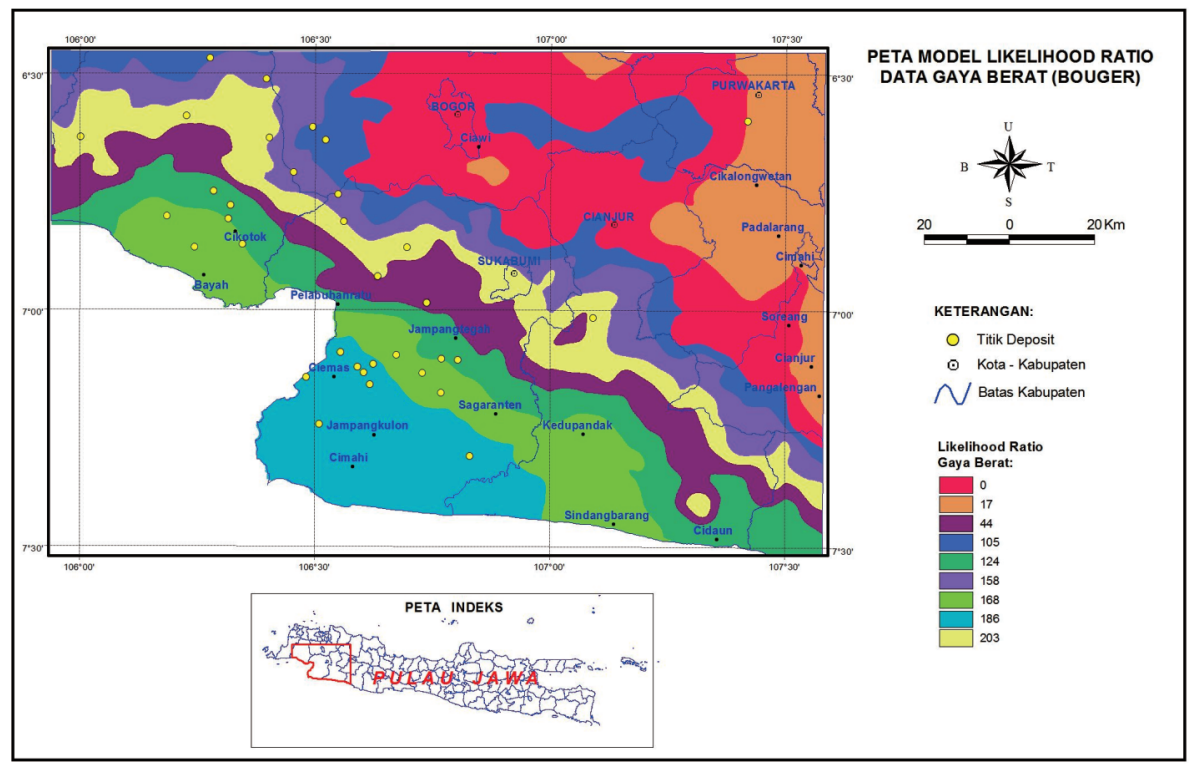

Gambar 13. Peta Model Likelihood Ratio Data Gaya Berat

Tabel 5.

Perhitungan Likelihood Ratio Unsur Cu Untur Faktor Atribut Data Geokimia.

\begin{tabular}{|c|c|c|c|c|c|c|c|}
\hline \multirow[b]{2}{*}{ Faktor } & \multirow[b]{2}{*}{ No } & \multirow[b]{2}{*}{ Kelas } & \multicolumn{2}{|c|}{ Domain } & \multicolumn{2}{|c|}{ Keterdapatan Mineral } & \multirow[b]{2}{*}{ LR } \\
\hline & & & Piksel & Persentase & $\begin{array}{l}\text { Jumlah } \\
\text { Lokasi }\end{array}$ & Persentase & \\
\hline \multirow{10}{*}{ Cu 10000} & 1 & $0-8$ & 178.911 & 10,71 & 24 & 21,05 & 1,97 \\
\hline & 2 & $9-16$ & 189.678 & 11,35 & 8 & 7,02 & 0,62 \\
\hline & 3 & $17-22$ & 189.590 & 11,35 & 20 & 17,54 & 1,55 \\
\hline & 4 & $23-27$ & 159.084 & 9,52 & 9 & 7,89 & 0,83 \\
\hline & 5 & $28-32$ & 191.658 & 11,47 & 12 & 10,53 & 0,92 \\
\hline & 6 & $33-36$ & 178.451 & 10,68 & 1 & 0,88 & 0,08 \\
\hline & 7 & $37-40$ & 150.751 & 9,02 & 0 & 0,00 & 0,00 \\
\hline & 8 & $41-46$ & 149.805 & 8,97 & 4 & 3,51 & 0,39 \\
\hline & 9 & $47-58$ & 143.535 & 8,59 & 6 & 5,26 & 0,61 \\
\hline & 10 & $59-407$ & 139.080 & 8,33 & 30 & 26,32 & 3,16 \\
\hline
\end{tabular}

Tabel 6.

Perhitungan Likelihood Ratio Untuk Faktor Atribut Struktur dan Data Bouguer.

\begin{tabular}{|c|c|c|c|c|c|c|c|}
\hline \multirow{2}{*}{ Faktor } & \multirow{2}{*}{ No } & \multirow{2}{*}{ Kelas } & \multicolumn{2}{|c|}{ Domain } & \multicolumn{2}{|c|}{ Keterdapatan Mineral } & \multirow{2}{*}{ FR } \\
\hline & & & Piksel & Persentase & $\begin{array}{l}\text { Jumlah } \\
\text { Lokasi }\end{array}$ & Persentase & \\
\hline \multirow{10}{*}{ Struktur } & 1 & $0-400$ & 172.128 & 10,30 & 23 & 20,18 & 1,96 \\
\hline & 2 & $412-900$ & 166.669 & 9,98 & 13 & 11,40 & 1,14 \\
\hline & 3 & $905-1552$ & 166.954 & 9,99 & 11 & 9,65 & 0,97 \\
\hline & 4 & $1555-2400$ & 167.474 & 10,03 & 8 & 7,02 & 0,70 \\
\hline & 5 & $2402-3500$ & 166.342 & 9,96 & 9 & 7,89 & 0,79 \\
\hline & 6 & $3501-4973$ & 166.247 & 9,95 & 16 & 14,04 & 1,41 \\
\hline & 7 & $4976-6830$ & 166.306 & 9,96 & 19 & 16,67 & 1,67 \\
\hline & 8 & $6835-9284$ & 166.258 & 9,95 & 3 & 2,63 & 0,26 \\
\hline & 9 & $9289-12932$ & 166.084 & 9,94 & 2 & 1,75 & 0,18 \\
\hline & 10 & $12934-25770$ & 166.081 & 9,94 & 10 & 8,77 & 0,88 \\
\hline \multirow{10}{*}{ Bouguer } & 1 & $19-935$ & 167.729 & 10,04 & 2 & 1,75 & 0,17 \\
\hline & 2 & $396-499$ & 173.130 & 10,36 & 0 & 0,00 & 0,00 \\
\hline & 3 & $500-593$ & 166.999 & 10,00 & 0 & 0,00 & 0,00 \\
\hline & 4 & $594-707$ & 166.936 & 9,99 & 12 & 10,53 & 1,05 \\
\hline & 5 & $708-869$ & 166.693 & 9,98 & 18 & 15,79 & 1,58 \\
\hline & 6 & 870 - 1014 & 166.259 & 9,95 & 23 & 20,18 & 2,03 \\
\hline & 7 & $1015-1166$ & 165.866 & 9,93 & 5 & 4,39 & 0,44 \\
\hline & 8 & $1167-1420$ & 166.062 & 9,94 & 14 & 12,28 & 1,24 \\
\hline & 9 & $1421-1816$ & 165.463 & 9,90 & 19 & 16,67 & 1,68 \\
\hline & 10 & $1817-2399$ & 165.256 & 9,89 & 21 & 18,42 & 1,86 \\
\hline
\end{tabular}




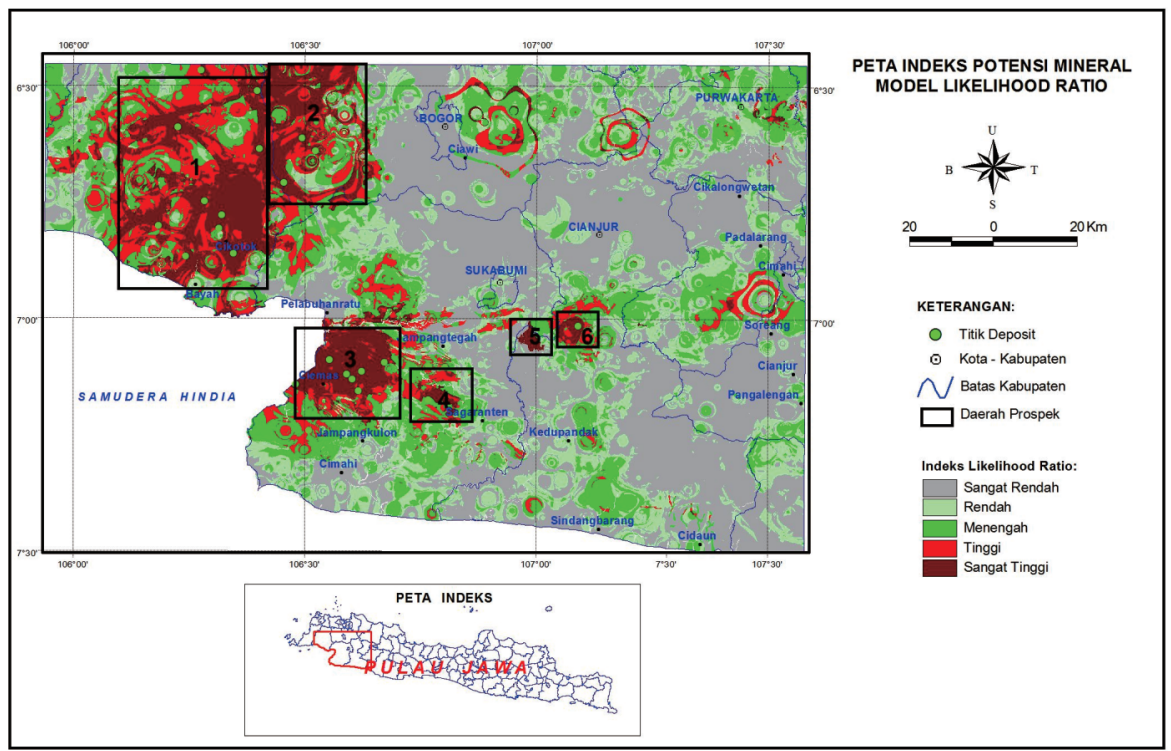

Gambar 14. Peta Indeks Potensi Mineral Model Likelihood Ratio

\section{PEMBAHASAN}

Hasil integrasi data keseluruhan menggunakan model likelihood ratio menghasilkan Peta Indeks Potensi Mineral dengan model likelihood ratio (Gambar.14). Pada peta tersebut menunjukkan bahwa sebagian besar daerah yang mempunyai indeks potensi keterdapatan mineral tertinggi yang ditunjukkan oleh area berwarna merah tua berada di bagian barat dari lokasi kajian, daerah prospek tersebut dibagi ke dalam enam blok sebagai berikut:

1. Blok 1: mencakup wilayah Bojongmanik, Leuwidamar, Cijaku, Panggarangan, Cibeber, dan Muncang (Kabupaten Lebak);

2. Blok 2: mencakup wilayah Kecamatan Sukajaya, Jasinga, Cigudeg, Nanggung, dan Leuwiliang (Kabupaten Bogor);

3. Blok 3: mencakup wilayah Kecamatan Pelabuhanratu, Ciemas, Lengkong, bagian utara Kecamatan Warungkiara dan Ciracap (Kabupaten Sukabumi);

4. Blok 4: mencakup wilayah Kecamatan Pabuaran (Kabupaten Sukabumi);

5. Blok 5: bagian utara Kecamatan Takokak (Kabupaten Cianjur).

6. Blok 6 : Kecamatan Campaka (Kabupaten Cianjur).

Lokasi-lokasi dengan nilai indeks tinggi tersebut diduga merupakan daerah yang memiliki mineralisasi emas dan perak sehingga disarankan untuk menjadi area kajian lebih lanjut.
Peta Potensi Mineral diverifikasi dengan membandingkan data lokasi deposit dengan peta potensi mineral. Setiap faktor dan likelihood ratio dibandingkan. Untuk mendapatkan peringkat relatif untuk setiap faktor, nilai indeks dihitung dari semua sel di daerah penelitian yang disortir dalam urutan. Nilai sel kemudian dibagi menjadi 100 kelas dengan interval 1.

Dalam kajian ini menunjukkan kelas $90-100 \%(10 \%)$ dengan indeks potensi mineral memiliki peringkat tinggi dapat menjelaskan $100 \%$ dari semua kemunculan mineral deposit. Hasilnya rasio 0,9104 daerah itu menunjukkan tingkat akurasi prediksi $91,04 \%$ untuk model likelihood ratio (Gambar .15).

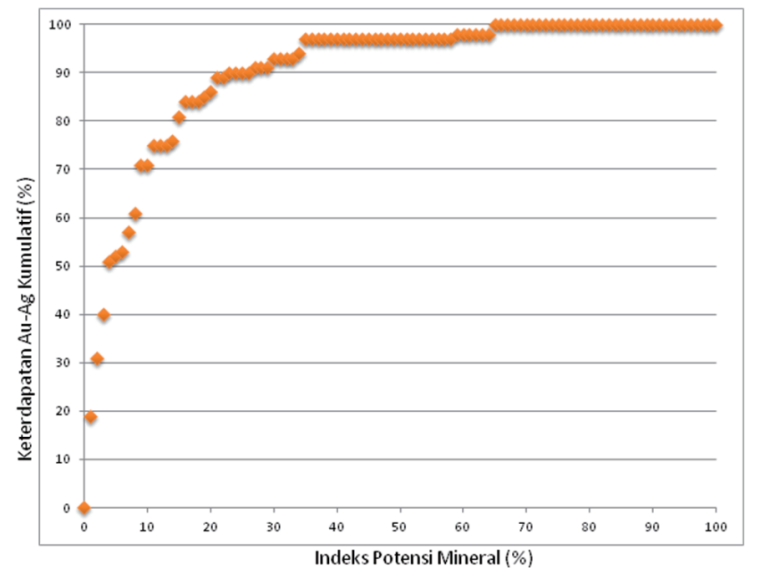

Gambar 15. Verifikasi model Likelihood Ratio.

Uji petik lapangan bertujuan untuk menguji hasil pengolahan data terutama 


\section{MAKALAH ILMIAH}

lokasi-lokasi yang bernilai indeks tinggi dengan kondisi di lapangan. Berdasarkan hasil peninjauan di beberapa lokasi terpilih dihasilkan bahwa daerah-daerah yang memiliki nilai indeks tinggi merupakan daerah yang mengandung mineralisasi emas dan perak yang umumnya merupakan wilayah pertambangan emas yang telah diusahakan dalam bentuk Ijin Usaha Pertambangan dan pertambangan rakyat.

Beberapa lokasi terpilih tersebut antara lain: Kecamatan Pelabuhanratu. Ciemas-Cigaru dan bagian utara Kecamatan Takokak (Tanggeung).

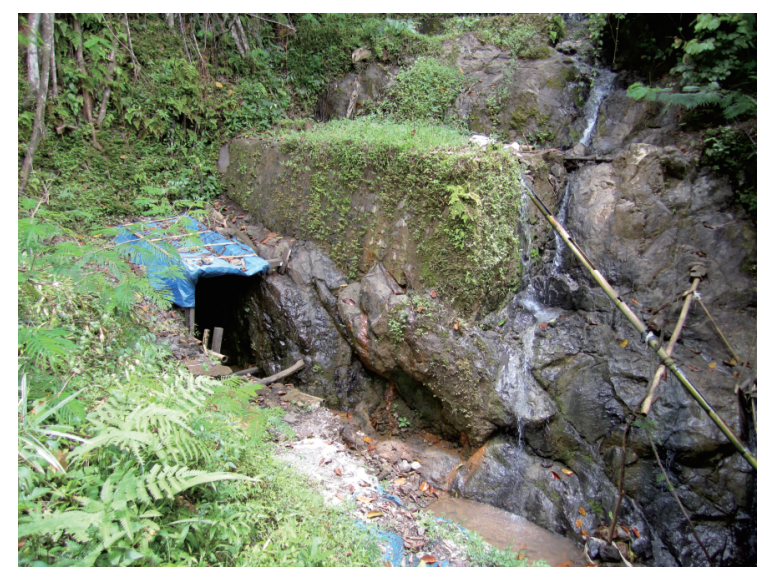

Gambar 16. Lubang Tambang Horisontal di Blok Ciemas

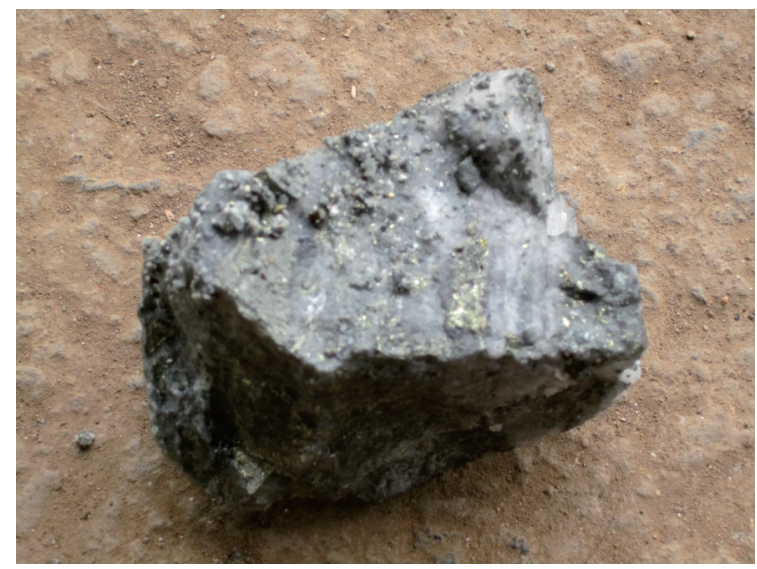

Gambar 17. Batuan Terkersikkan mengandung kalkopirit, pirit, galena, sfalerit di Blok Ciemas.

\section{KESIMPULAN}

1. Terdapat enam daerah prospek mineralisasi emas dan perak yang ditunjukkan dengan nilai indeks yang relatif lebih tinggi dibanding daerah lainnya.

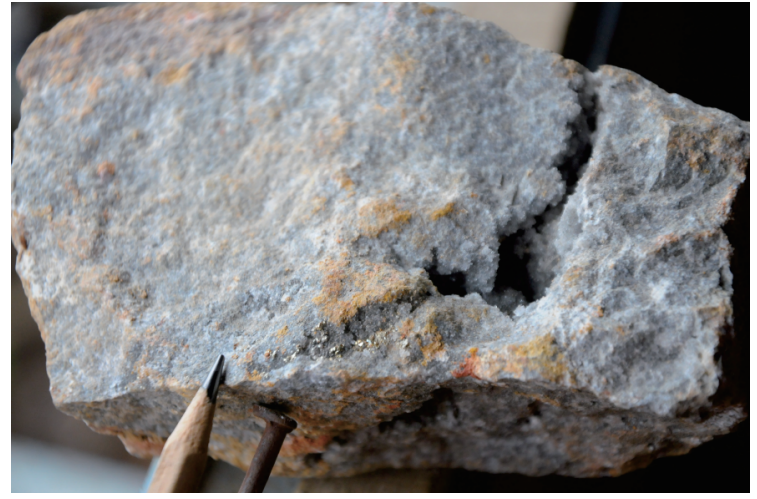

Gambar 18. Batuan terkersikkan, berongga, mengandung kalkopirit dan pirit di Blok Tanggeung, Cianjur.

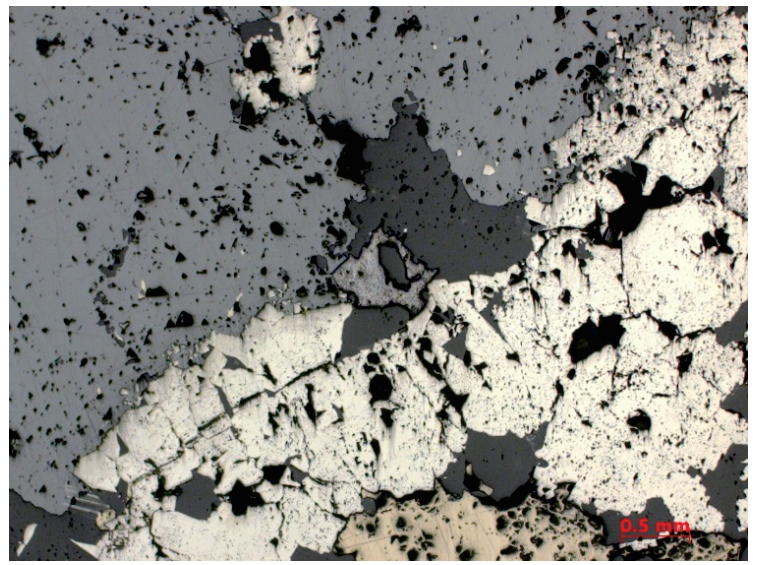

Gambar 19. Sayatan Mineragrafi yang menunjukkan mineral pirit, kalkopirit, galena, dan sfalerit pada diorit porfir di daerah Ciemas-Cigaru, Kabupaten Sukabumi.

2. Berdasarkan hasil uji petik di 3 (tiga) lokasi prospek menunjukkan bahwa daerah-daerah prospek mineralisasi tersebut telah dilakukan penambangan oleh rakyat dalam skala kecil.

3. Penggunaan metode analisis spasial "likelihood ratio" dapat mendeliniasi daerah-daerah prospek mineralisasi berdasarkan data sekunder yang tersedia namun tidak dapat menunjukkan besaran sumber daya dan cadangannya.

\section{UCAPAN TERIMAKASIH}

Ucapan terimakasih disampaikan kepada Kepala Pusat Sumber Daya Geologi, Kepala Pusat Survey Geologi dan Kepala Bidang Informasi dan yang telah memberikan kesempatan kepada penulis 
untuk memperoleh data dan menyelesaikan makalah ini. Selanjutnya ucapan terimakasih disampaikan pula kepada pengelola Buletin
Sumber Daya Geologi yang telah memberikan saran untuk perbaikan penulisan hingga artikel ini dimuat dalam Buletin.

\section{DAFTAR PUSTAKA}

Bonham-Carter, 1994. Geographic Information System For Geoscientist, Pergamon, Ontario, Canada.

Effendi, A.C., Kusnama, dan Hermanto, B., 1998. Peta Geologi Lembar Bogor, Jawa, Skala 1 : 100.000. Pusat Penelitian dan Pengembangan Geologi, Bandung.

Henry L. Alder \& Edward B. Roessler, 1972. Introduction to Probability and Statistics. W.H.freeman \& Company, San Francisco, USA.

Koesmono, Kusnama, M., dan Suwarna, N., 1996. Peta Geologi Lembar Sindangbarang dan Bandarwaru, Jawa, Skala 1 : 100.000. Edisi Kedua. Pusat Penelitian dan Pengembangan Geologi, Bandung.

Kuzvart M \& Bohmer M, 1986, Prospecting and Exploration of Mineral Deposits, Elsevier, Amsterdam-Oxford-Newyork-Tokyo.

Lee and Oh, 2008, Regional Probabilistic and Statistical Mineral Potential Mapping of GoldSilver Deposits Using GIS in the Gangreung Area, Korea, Resource Geology vol.58, no.2:1-17.

Nainggolan, D.A., Hutubessy, S., dan Suharyono, S., 1995. Peta Anomali Bouger Lembar Sindangbarang, Jawa Skala 1 : 100.000. Pusat Penelitian dan Pengembangan Geologi, Bandung.

Nasution, J dan Sobari, I., 1994. Peta Anomali Bouger Lembar Cianjur, Jawa Skala 1 : 100.000. Pusat Penelitian dan Pengembangan Geologi, Bandung.

Nasution, J dan Tasno, P., 1990. Peta Anomali Bouger Lembar Leuwidamar, Jawa Skala 1 : 100.000. Pusat Penelitian dan Pengembangan Geologi, Bandung.

Rifki Febrianto. 2011, Geologi dan Studi Alterasi Hidrotermal Daerah Andulan Kecamatan Walenrang Utara Kabupaten Luwu Propinsi Sulawesi Selatan. Yogyakarta : Universitas Pembangunan Nasional "Veteran", Jogjakarta.

Rohandi, U dan Gunawan, W., 1990. Peta Anomali Bouger Lembar Jampang, Jawa Skala 1 : 100.000. Pusat Penelitian dan Pengembangan Geologi, Bandung.

Rohandi, U dan Sani, M., 1990. Peta Anomali Bouger Lembar Bogor, Jawa Skala 1 : 100.000. Pusat Penelitian dan Pengembangan Geologi, Bandung.

Sujatmiko, 1972. Peta Geologi Lembar Cianjur, Jawa, Skala 1 : 100.000. Pusat Penelitian dan Pengembangan Geologi, Bandung.

Sujatmiko dan Santosa, S., 1992. Peta Geologi Lembar Leuwidamar, Jawa, Skala 1 : 100.000. Pusat Penelitian dan Pengembangan Geologi, Bandung.

Sukamto, R., 1975. Peta Geologi Lembar Jampang dan Balekambang, Jawa, Skala 1 : 100.000. Pusat Penelitian dan Pengembangan Geologi, Bandung 